\title{
TRIDIMENSIONAL (3D) MODELING OF TRUNKS AND COMMERCIAL LOGS OF Tectona grandis L.f.
}

\author{
Arthur Guilherme Schirmbeck Chaves ${ }^{*}$, Carlos Roberto Sanquetta ${ }^{2}$, Júlio Eduardo Arce², Luiz Orlando dos \\ Santos$^{1}$, Iuri Maicon Moreira de Oliveira ${ }^{1}$, Fernanda Miguel Franco ${ }^{1}$
${ }^{1}$ Instituto Federal de Mato Grosso, Cáceres, Mato Grosso, Brasil - arthur.chaves@ cas.ifmt.edu.br*; luizorlando.st@gmail.com; iurii.moreiira@gmail.com; fernanda.franco@cas.ifmt.edu.br
${ }^{2}$ Universidade Federal do Paraná, Curitiba, Paraná, Brasil - carlos_sanquetta@ hotmail.com; julioarce@optimber.com.br

Recebido para publicação: 03/09/2017 - Aceito para publicação: 05/12/2017

\begin{abstract}
The development and application of technological innovations have been some of the main focuses of the productive sectors. One technological innovation that has been gaining prominence is the three-dimensional modeling (3D) of inventory and forest planning activities. In this study, it was possible to assess the accuracy of three-dimensional scanning of trunks of Tectona grandis L.f. by digital photogrammetry by using photos taken with a smartphone. The study was carried out in a Teak plantation of 46.54 ha. Systematic sampling by plots was used. Based on the diametric distribution of the stand, thirty trees were selected for the threedimensional scanning procedure by the Close to Range technique. After three-dimensional scanning, each tree was scaled by the Smalian method and sectioned into 2.35 meters long logs for assessment using the xylometer method. The thirty trees resulted in 121 logs that had their volumes measured using the xylometer. Using threedimensional modeling, it was possible to model and measure the volume of $71 \mathrm{logs}$ in classes A (0.10 to 2.45), B (2.45 to 4.80), and C (4.80 to 7.15). The trunk of the trees could not be modeled for all trees at the highest heights because of the quality of the cloud of data points. Records that could not be entirely modeled ( 2.35 meters) were ignored. The cubing methods were compared by the paired t-test. Therefore, it was possible to model lower logs $(0.10 \mathrm{~m}$ to $2.45 \mathrm{~m})$ more accurately than by using the traditional Smalian method, with a one-meter interval between sections.
\end{abstract}

Keywords: Scaling, teak, xylometer, scanning, close to range.

\section{Resumo}

Modelagem Tridimensional (3D) de fustes e toras comerciais de Tectona grandis L.f. O desenvolvimento e aplicação de inovações tecnológicas vêm sendo alguns dos principais focos dos setores produtivos. Uma inovação tecnológica que vem ganhando destaque é a modelagem tridimensional (3D) das florestas em atividades de inventário e planejamento florestal. Neste trabalho, foi possível avaliar a acurácia do escaneamento tridimensional de fustes para Tectona grandis L.f. por meio da fotogrametria digital, empregando fotos retiradas com smartphone. O estudo foi desenvolvido num plantio de Teca de 46,54 ha. Foi empregado o processo de amostragem sistemático por parcelas. Com base na distribuição diamétrica do povoamento, trinta árvores foram selecionadas para o procedimento de escaneamento tridimensional pela técnica Close to Range. Após o escaneamento tridimensional, cada árvore foi cubada pelo método de Smalian e seccionada em toras de 2,35 metros de comprimento para avaliação pelo método do xilômetro. As trinta árvores resultaram em 121 troncos, que tiveram seus volumes medidos usando xilômetro. Usando modelagem tridimensional, foi possível modelar e medir o volume de 71 toras nas classes A $(0,10$ a 2,45), B $(2,45$ a 4,80) e C $(4,80$ a 7,15$)$. $\mathrm{O}$ tronco das árvores não pode ser modelado para todas as árvores nas alturas mais altas devido à qualidade da nuvem de pontos de dados. Os registros que não puderam ser modelados inteiramente (2,35 metros) foram ignorados. Os métodos de cubagem foram comparados pelo teste de t pareado. Assim, foi possível modelar as toras inferiores $(0,10 \mathrm{~m}$ a $2,45 \mathrm{~m})$ com maior acurácia do que com o método tradicional de Smalian com intervalo entre secções de um metro.

Palavras-Chave: Cubagem, Teca, xilômetro, escaneamento, fotogrametria de proximidade.

\section{INTRODUCTION}

The use of geotechnology is among the most important technological innovations of the forestry sector, as it collects information with geographic or spatial references. For instance, Carvalho et al. (2015) report the use of LiDAR (Light Detection and Ranging) for a census of tree heights and account of individuals in a forest. The authors also report the possibility of obtaining diameter values at breast height $(\mathrm{DBH})$ of sampled trees. Other authors, such as Buck et al. (2014) and Rodriguez et al. (2010), have also performed direct and indirect volumetric estimations by

FLORESTA, Curitiba, PR, v. 48, n. 2, p. 225-234, abr/jun. 2018.

Chaves. A. G. S. et.al.

ISSN eletrônico 1982-4688

DOI: $10.5380 /$ rf.v48 i 2.55224 
using LiDAR. However, according to Figueiredo et al. (2016) and Robleda and Pérez (2015), the cost of such alternatives exceeds 200,000 dollars per operating unit (LiDAR and software).

Photogrammetry with micro RPA/UAVs (Unmanned Aerial Vehicles) seems to be a viable alternative for different forest engineering applications. According to Figueiredo et al. (2016), volumetric estimation by using digital scanning of forests can improve the use of precision techniques in planning of forestry harvesting. As the price of such technology is dropping fast, the use of drones by companies has been increased in frequency.

Whereas the field of drones and robotics is still emerging, image-based three-dimensional (3D) reconstruction and modeling techniques have reached maturity. Structure from motion (SfM), a photogrammetric range imaging technique for estimating 3D structures, is a well-studied topic, and several other methods have appeared in the last few years. Such techniques claim accuracy comparable to laser range sensor systems at a fraction of the cost. Close-range photogrammetry represents a cost-efficient alternative to conventional 3D scanning (DEAN, 2003; LUHMANN, 2010; GUO et al., 2016; ROBLEDA; PÉREZ, 2015).

By using stereoscopic principles and algorithms that determine parallax (horizontal distance between images) for example, it is possible to calculate the third dimension, or depth dimension (distance to pixels), of two plane coordinates. A wide range of proprietary or free software is available for point cloud extraction and 3D modeling. The main differences among softwares are processing platform, automatic modeling potential, modeling quality, and type of photographic acquisition that can be processed: Close Range, Airborne by Satellites, Airborne (Airplanes), and Air by UAVs (UAS). Each software employs its own algorithms, and most of these algorithms are not available to users.

Logging of tree trunks generally uses the destruction of sample trees. During scaling (volume measurement), an average of two diameters obtained in each measured height is considered. An engineer may disregard the irregularity (complex forms different from a circle or an ellipse) of these sections. A forester may not consider a tortuosity along the trunk. The destructive felling process of trees is burdensome and does not always yield satisfactory results.

Therefore, the objective of this study was to evaluate the use of a photogrammetry technology called "Close Range Technique" for the reconstruction of the 3D volumetry of commercial trunks of Teak.

\section{MATERIAL AND METHODS}

The property for the study was the Fazenda Mineira, located on the edge of the highway BR-070, 15 kilometers from the municipality of Cáceres (state of Mato Grosso, Brazil). The headquarters of the farm are circumscribed to the geographical coordinates of $16^{\circ} 12^{\prime} 03^{\prime}$ 'S and $57^{\circ} 36^{\prime} 33^{\prime \prime} \mathrm{W}$. Currently, the farm practices cattle breeding, fishery and forestry. The total area of Teak plantations is approximately 46.54 hectares (Figure 1).

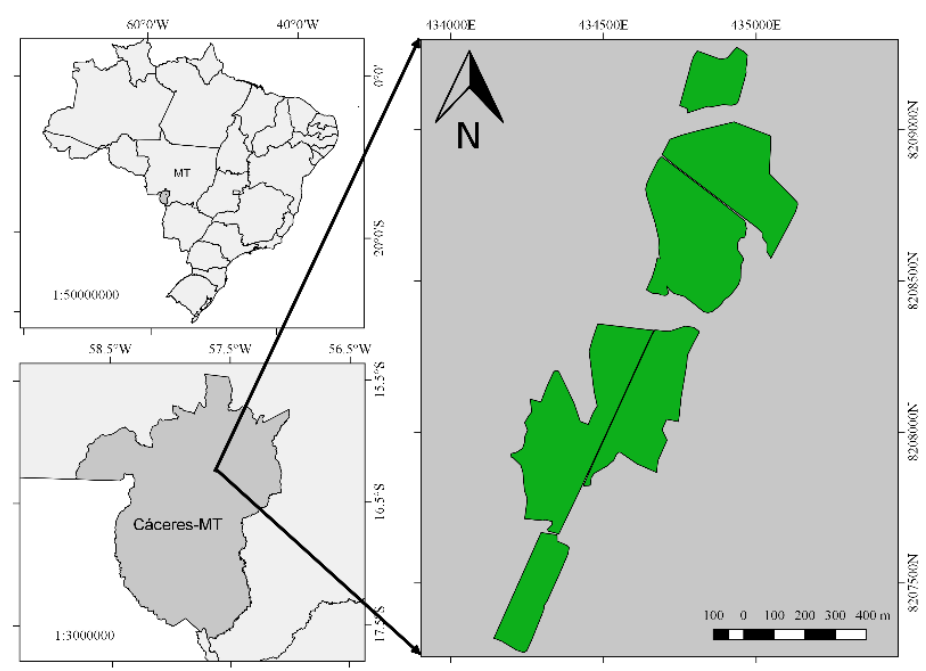

Figure 1. Location map of Teak compartments in the municipality of Cáceres, state of Mato Grosso, Brazil. Figura 1. Mapa de localização dos talhões de Teca no município de Cáceres, Mato Grosso. 
The forest inventory was carried out on forest compartments by multiclonal genetic material (46.54 ha). The sampling process was systematic for plots with sample intensity of one plot per 2.6 hectares, totaling 18 plots of $720 \mathrm{~m}^{2}(24 \mathrm{~m} \mathrm{x} 30 \mathrm{~m})$. In each plot, the following measurements were taken: diameter at breast height (DBH) of $100 \%$ of individuals; and commercial height (hc), and total height (ht) of six individuals per plot (10\%). The respective diametric distribution was taken into account.

Based on inventory data, histograms of frequency of diameters were plotted in classes with intervals of 1.5 centimeters. Following this proportion, thirty individuals with diameter distribution close to the one obtained from the forest inventory were selected.

Through random walk, and due to a diametrical distribution of each compartment, thirty trees were selected. In each compartment, approximately five trees were measured. The procedure for 3D scanning followed the steps below:

a) Confirmation of desired DBH class with tape measurements;

b) Cleaning of leaves on the ground that could prevent the visualization of the trunk base;

c) Demarcation of tree number with spray paint on the trunk south face using a compass.

d) Demarcation of circumferences at $0.10 \mathrm{~m}$ and 1.30 meter of height of the trunk using a red tape;

e) $360^{\circ}$ photographic rotation around the trunk, framing its base to the commercial height of the trunk (30 to 50 photos). The photos were taken by using a Samsung Galaxy J5 smartphone with regular frame-to-boom distance at the height of the observer (photographer).

Then, the tree was felled by using chainsaw at cutting height of about 10 centimeters. The scaling procedure followed the traditional methodology of Smalian by measuring stump height, commercial height and total height of the tree, as well as the two transverse diameters, using a caliper at heights $0.10,0.70,1.30,2.30$, and every meter up to the commercial height. The trunk volume was calculated according to the Smalian (1).

$$
V=\sum_{i=1}^{n-1}\left(\frac{g_{i}+g_{i+1}}{2} * L\right)
$$

In which: $V=\log$ volume $\left(\mathrm{m}^{3}\right) ; n$ : number of sections; $g_{i}=$ cross-sectional area of the lower section $\left(\mathrm{m}^{2}\right) ; g_{i+1}=$ area of the upper cross-section $\left(\mathrm{m}^{2}\right) ; L=$ section length $(\mathrm{m})$.

After the Smalian absolute scaling, the tape-measure was "set to zero" at the beginning of the trunk to demarcate every 2.35 meters, by tracing points in logs. The logs were classified in ascending order of $\log \mathrm{A}(0.10 \mathrm{~m}$ to $2.45 \mathrm{~m}), \log \mathrm{B}(2.45 \mathrm{~m}$ to $3.80 \mathrm{~m}), \log \mathrm{C}(3.80 \mathrm{~m}$ to $7.15 \mathrm{~m})$, and so on, up to the commercial height. On each $\log$, a number and a trunk class were marked using spray paint.

A xylometer of 0.80 meters in diameter and 3.00 meters in height was constructed for immersion and measurement of log volume. An external level embraced with transparent hose was installed to verify the height variation of water inside the xylometer. For this instrument, according to xylometer formula 2, the variation of one linear meter of water depth was equivalent to the volume of 0.5 cubic meter.

$$
V=\Delta L * g_{x i l}
$$

In which: $V=$ Volume $\left(\mathrm{m}^{3}\right) ; \Delta L=$ change in water level after full submergence of log $(\mathrm{m}) ; g_{x i l}=$ cross-sectional area of the water column contained in the $\mathrm{x}$-meter $\left(\mathrm{m}^{2}\right)$.

The images collected from each one of the thirty individuals were processed by using a digital photogrammetry software (Agisoft PhotoScan) to create the textured 3D surface. The software operates according to the following steps:

a) Identification of pixels or reference points for alignment and positioning of photos and pixels;

b) Dense cloud construction;

c) Construction of a polygonal surface by triangulation of dense cloud points;

d) Polygonal surface texturization.

The textured 3D surface was transformed into real scale, using the reference points of distance between red tapes at 0.1 and 1.3 meter high. Then, the 3D textured surface was transformed into a solid object using another software (Autodesk Meshmixer). The object was sectioned according to logs classes: A (0.10 m to $2.45 \mathrm{~m})$, $\mathrm{B}(2.45 \mathrm{~m}$ to $3.80 \mathrm{~m}), \mathrm{C}(3.80 \mathrm{~m}$ to $7.15 \mathrm{~m})$, and so on, up to the commercial height. The volume of each log was calculated automatically.

FLORESTA, Curitiba, PR, v. 48, n. 2, p. 225-234, abr/jun. 2018.

Chaves. A. G. S. et.al.

ISSN eletrônico 1982-4688

DOI: $10.5380 /$ rf.v48 i 2.55224 
In order to compare the tree frequencies regarding diametric distributions of the inventory with trees selected for modeling, the $\mathrm{X}^{2}$-test was used, following the hypotheses:

$$
\left\{\begin{array}{l}
H 0: p=p 0 \\
H 1: p \neq p 0
\end{array}\right.
$$

In which: H0: frequencies observed are not different from expected frequencies, i.e., there is no difference between frequencies (counts) of the groups; H1: frequencies observed are different from expected frequencies, i.e., there is a difference between frequencies.

The graph of "real volumes" obtained by using the xylometer $\left(Y_{i}\right)$ in face of the calculated volumes $\left(\hat{Y}_{\mathrm{i}}\right)$ was used. The graph of log volumes was also used constrasting with the calculated error (3).

$$
\operatorname{Error}(\%)=\frac{\hat{Y} \mathrm{i}-Y i}{\hat{Y} \mathrm{i}} * 100
$$

For the statistical analysis of the difference between volumes, a paired t-test was used to test the following hypotheses:

$$
\left\{\begin{array}{l}
H 0: \mu d=\mu 0 \\
H 1: \mu d \neq \mu 0
\end{array}\right.
$$

In which: H0: mean of volume differences $(\mu \mathrm{d})$ is equal to the hypothetical average of differences $(\mu 0)$, i.e., there is no difference between volumes; H1: mean of volume differences $(\mu \mathrm{d})$ is not equal to the hypothetical average of differences $(\mu 0)$, i.e., there is a difference between volumes.

\section{RESULTS}

At the age of six years, the clonal settlement of Tectona grandis L.f. presented high frequency of individuals $(32.9 \%)$ in the class $20-21.5 \mathrm{~cm}$ of diameter at breast height (DBH), with total amplitude of 16.5 centimeters $(11-27.5 \mathrm{~cm})$. Following the diametric distribution of the plots, $10 \%$ of the trees had their heights also measured (Figure 2).

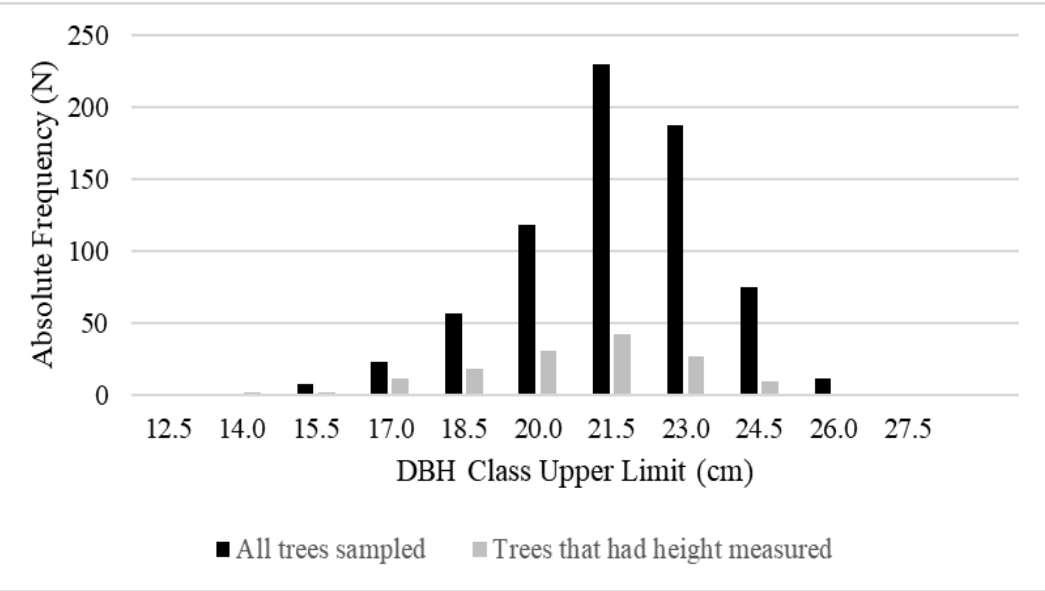

Figure 2. Diametric distribution of all trees sampled in the forest compartments.

Figura 2. Distribuição diamétrica de todas as árvores amostradas nos talhões florestais.

One hundred and fourteen trees had their total and commercial heights measured within the eighteen systematically distributed plots. The averages of total height and commercial height of all trees were, respectively, sixteen and eight meters. 
Table 1. Descriptive statistics of variables evaluated in the forest inventory.

Tabela 1. Estatística descritiva das árvores das variáveis avaliadas no inventário florestal.

\begin{tabular}{|c|c|c|c|}
\hline & DBH (cm) & Total Height (m) & Commercial Height (m) \\
\hline \multicolumn{4}{|c|}{ Descriptive Statistics of all sampled trees } \\
\hline Average & 20.72 & 15.90 & 8.36 \\
\hline Standard deviation & 0.19 & 0.10 & 0.11 \\
\hline Minimum & 12.57 & 12.40 & 4.40 \\
\hline Maximum & 26.90 & 18.40 & 11.60 \\
\hline $\mathrm{N}^{\circ}$ of Trees & 114 & 114 & 114 \\
\hline \multicolumn{4}{|c|}{ Descriptive Statistics for the sampled plots } \\
\hline Average & 20.75 & 15.95 & 8.39 \\
\hline Standard deviation & 0.28 & 0.18 & 0.16 \\
\hline Minimum & 17.02 & 14.10 & 7.27 \\
\hline Maximum & 22.31 & 17.00 & 9.40 \\
\hline $\mathrm{N}^{\circ}$ of Plots & 18 & 18 & 18 \\
\hline
\end{tabular}

Following the ratio of the diameter distribution observed in the forest inventory, the selection of thirty trees was performed for scaling the volumes. The $\mathrm{X}^{2}$-test indicated that there was no difference between the diameter distribution predicted for sampling and the effectively sampled distribution of the thirty trees $(\mathrm{H} 0$ : fo $=\mathrm{fe})$ at $95 \%$ confidence, because calculated $\mathrm{X}^{2}(6.20)$ was lower than the tabulated $\mathrm{X}^{2}$ (11.07) (Figure 3).

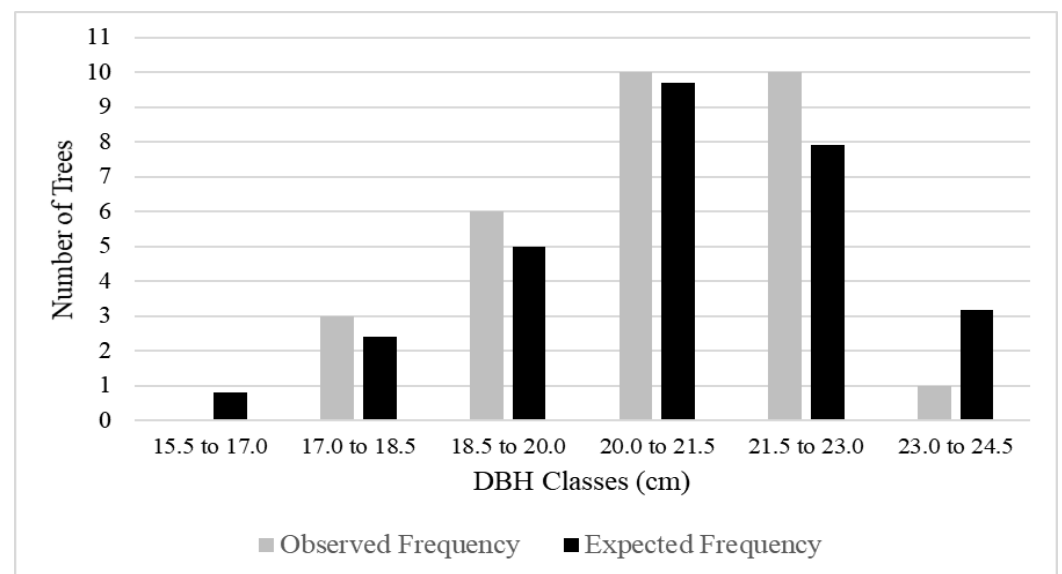

Figure 3. Expected frequency and observed frequency for trees sampled for 3D modeling.

Figura 3. Frequência esperada e frequência observada para árvores amostradas para modelagem tridimensional.

The thirty sampled trees were scanned, as for commercial scans, using 40 photos on average, taken around $\left(360^{\circ}\right)$ each tree. The lowest number of photos was 32, and the maximum was 50. The photographer held the smartphone at the height of his head and followed the natural slope of the terrain. The pictures were always taken at the same height.

The trunk of the trees could not be modeled for all trees at the highest heights due to the quality of the cloud of data points. Thus, the average modelable height was 6.54 meters; the maximum height was 9.39 meters; and the lowest height was 3.22 meters. Most individuals (70\%) could be modeled above six meters in height.

The impossibility of modeling trunks for the highest heights may be explained by two factors: presence of branches in the trunk and irregular luminosity due to light incidence contrary to the camera; or the time when the photos were taken. Both factors prevented or disrupted the modeling of the trunks (Figure 4). 


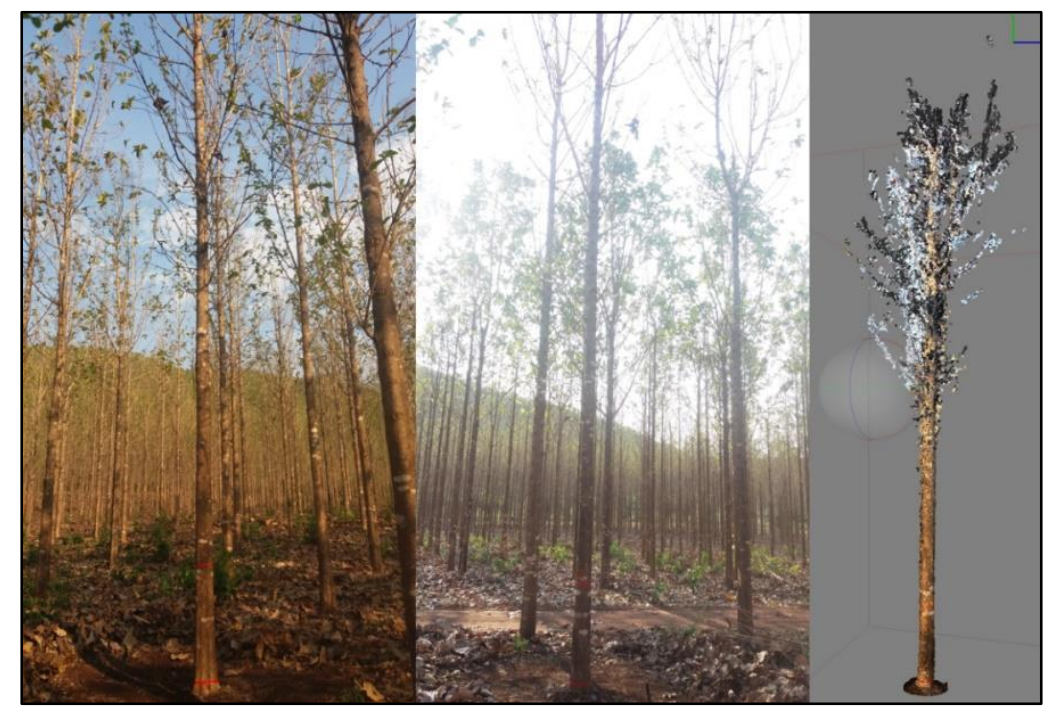

Figure 4. Irregular brightness and branches presence in photographs hinder the modeling of trunks.

Figura 4. Luminosidade irregular e presença de galhos nas fotografias atrapalhando a modelagem dos troncos.

It was necessary to perform a "virtual pruning" to clean the cloud of points before the construction of the $3 \mathrm{D}$ modeling. Considering that the logs were marked every 2.35 meters from the height of the stump (approximately 10 centimeters), $87 \%$ of the individuals could have at least the first two commercial shaped logs (A and B), and $37 \%$ could have three logs (A, B and C).

Using 3D modeling, it was possible to model and measure the volume of $71 \mathrm{logs}$ in classes A $(0.10$ to 2.45), B (2.45 to 4.80$)$ and $\mathrm{C}$ (4.80 to 7.15$)$. Logs that could not be modeled entirely (2.35 meters) were disregarded.

The thirty trees resulted in 121 logs, which had their volumes measured using the xylometer. All 121 logs could also have their volume calculated using the Smalian methodology, by linear interpolation between the sections 0.10 to $2.45(\log A), 2.45$ to $4.80(\log B)$, and so on, at each successively 2.35 meters up to the commercial height.

Considering the whole stem, the traditional Smalian cube, with intervals of one meter sections, resulted in normally distributed errors of approximately $\pm 35 \%$ (Figure 5). However, the paired t-test indicated that there was a significant difference (95\% confidence) between Smalian and Xilometer volumes $(\mathrm{H} 1: \mu \mathrm{d} \neq \mu 0)$, since the calculated t-value (2.64) was greater than the tabulated t-value (1.98).

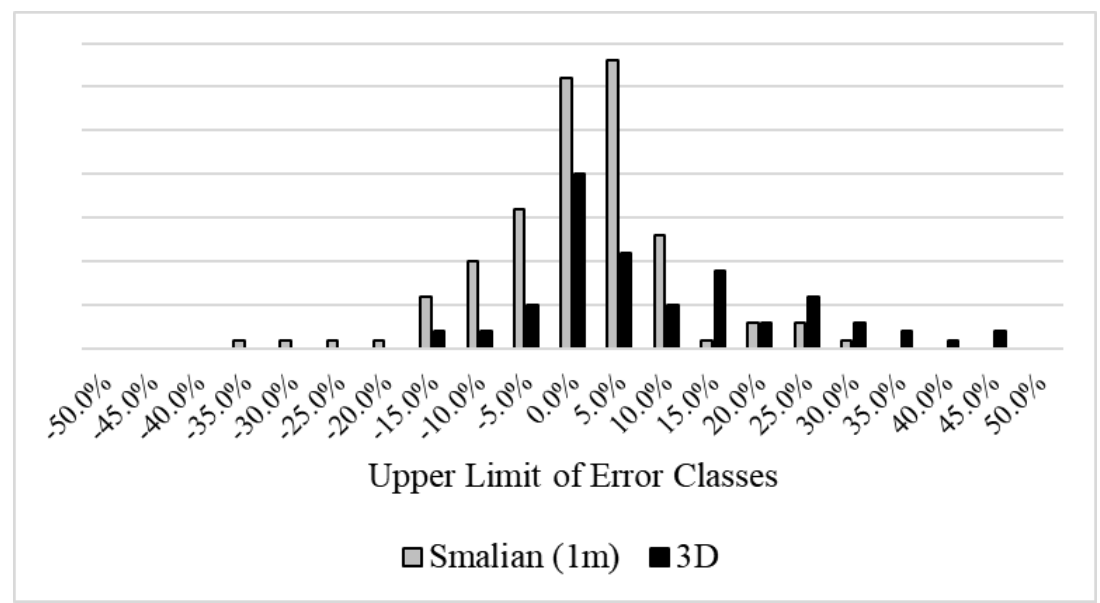

Figure 5. Histogram of volume errors for the two scaling methods.

Figura 5. Histograma dos erros do volume para os dois métodos de cubagem. 
The 3D modeling was biased, with high asymmetry to the right. The estimated $3 \mathrm{D}$ volumes tended to underestimate the volumes of the logs, especially for upper logs.

Analysing the volumetric performance of each log class (A, B, C, D and E), it was found that the first commercial $\log (\mathrm{A})$ had its volume estimated with greater accuracy by the 3D modeling than by the Smalian traditional scaling technique (Figure 9). The paired t-test indicated that there was no significant difference ( $95 \%$ confidence) between $3 \mathrm{D}$ volumes and xylometer volumes $(\mathrm{H} 0: \mu \mathrm{d}=\mu 0)$, since the calculated $\mathrm{t}(-0.44)$ was lower than the tabulated $\mathrm{t}$ (2.05). The same test indicated a significant difference (95\% confidence) between the volumes of Smalian (1 meter) and the volumes of Xylometer $(\mathrm{H} 1: \mu \mathrm{d} \neq \mu 0)$, because the calculated $\mathrm{t}$-value (5.49) was higher than the tabulated t-value (2.05).

In the second log case (B), the situation was reversed: the Smalian estimate obtained satisfactory results, whereas the $3 \mathrm{D}$ volume tended to underestimate $11 \%$ of the volume of logs in average, with maximum error of $44 \%$ (Figure 6). For C logs, the Smalian method was more accurate for volume estimation, whereas the tendency to underestimate the volumes by the 3D method increased.

In the case of logs D and E, Smalian method had good accuracy, whereas the 3D modeling could not be used because of an impossibility of reconstruction of the trunk surface caused mainly by the interference of the branches at the top of the canopy, or due to light facing the photograph.

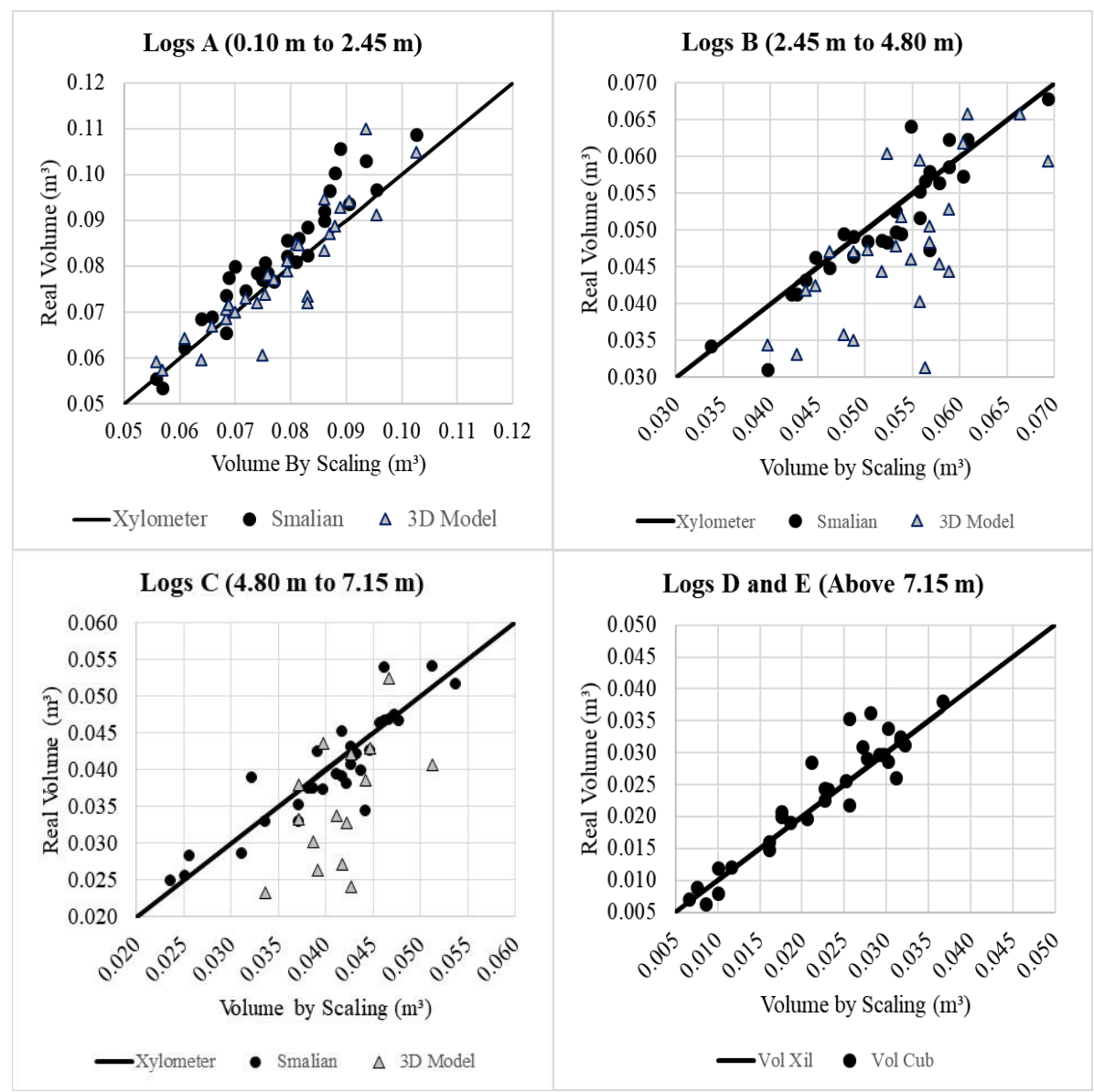

Figure 6. Performance scaling methods for each log class.

Figura 6. Desempenho dos métodos de cubagem para cada classe de tora.

For each log class, the paired t-test was performed to verify accuracy (Table 2).

FLORESTA, Curitiba, PR, v. 48, n. 2, p. 225-234, abr/jun. 2018.

Chaves. A. G. S. et.al.

ISSN eletrônico 1982-4688 
Table 2. Accuracy of scaling methods for each log class.

Tabela 2. Acurácia dos métodos de cubagem para cada classe de tora.

\begin{tabular}{cccccc}
\hline Method & Log Class & Calculated t-value & Two-tailed t-value (95\%) & Degrees of freedom & Accuracy \\
\hline Smalian & A & -5.49 & \pm 2.05 & 29 & NO \\
Smalian & B & 1.37 & \pm 2.05 & 29 & YES \\
Smalian & C & 0.84 & \pm 2.05 & 29 & YES \\
Smalian & D,E & -1.88 & \pm 2.04 & 30 & YES \\
3D & A & -0.44 & \pm 2.05 & 29 & YES \\
3D & B & 4.11 & \pm 2.06 & 25 & NO \\
3D & C & 3.52 & \pm 2.14 & 14 & NO \\
3D & D,E & - & - & - & - \\
\hline
\end{tabular}

Some factors that may explain such a lack of accurate 3D modeling are the presence of branches and nodes and the methodology of photographic collection for the Close to Range technique. The Close to Range technique is more successful when images are collected at different heights. In this methodology, the ideal is that the $3 \mathrm{D}$ object is imaged under all possible viewing angles at the same distance from the object, as in a symmetrical "bubble".

The methodology used for the 3D scanning with digital photogrammetry software still needs to be improved, taking into account factors such as calibration of the camera, arrangement and quality of images taken from stem, correction of image distortion effects, presence of branches, luminosity, and softwares and algorithms used for modeling.

\section{DISCUSSION}

Most studies regarding tridimensional modeling in forest inventories were executed by using terrestrial LiDAR scanners (BUCK et al., 2012; BUCK et al., 2014; CARVALHO et al., 2015; DEAN, 2003; MAAS et al., 2008; MARTINS NETO, 2013). The hardest issue for LiDAR users is the cost of equipaments, in addition to the necessity of developing methods and algorithms for automatic detection of trees, diameter at breast height $(\mathrm{DBH})$, tree height, and 3D stem profiles. The advantage of use photogrammetry was the lower cost (no LiDAR equipament), besides the possibility of non-expert users to easily execute the Close to Range technique to obtain volume or shape of the trunks with available softwares.

Some problems are present in both methodologies (LiDAR and Photogrammetry). For example, the lower quality of modeling upper parts of trunks, as presented in this study, was also pointed by other authors using LiDAR. Martins Neto et al. (2013) observed tendencies of underestimation for the diameters in upper parts of the trunk using data obtained with terrestrial LiDAR. Oliveira et al. (2014), using aerial LiDAR, reported tendency to underestimate the trees height in 5\%, and total timber volume in the stand in $11.4 \%$.

Buck et al. (2012) and Buck et al. (2014) reported that the presence of branches resulted in decrease in the density of points, mainly in the upper parts of trees, hindering the 3D modeling. Dean (2003), using terrestrial Single-Image Close to Range Photogrammetry, explained that images rectification process assumes that all points in the image lay in the object plane, unless it is specified, i.e. in the plane containing the centre line of the trunk and facing the camera. Thus, many branches end up moving away from the central point of the modeled object in several directions (diffuse), making it difficult for the algorithm to find common pixels among images.

Maas et al. (2008), using terrestrial LiDAR scanners, reported problems of occlusion by ground vegetation. In this study, there was no such problem, as the commercial forests of teak have less complex structure and few plants in sub forest. Martins Neto et al. (2013) stated that it is necessary to perform a point filtering to clean the cloud of points before the construction of the 3D modeling. Martins Neto et al. (2013) explained that a poor representation in the cloud of points of upper parts of the stem leads to a substantial underestimation of the volume of such sections.

According to Luhmann et al. (2016), accurate intrinsic camera calibration is critical for most computer viewing methods involving image-based measurements. Traditional SfM pipelines (Bundler, Agisoft, etc.) use direct uncalibrated views for 3D reconstruction and may inherently deal with dataset of images taken with varying focal length, scale and resolution. Ducke et al. (2011) highlighted the importance of algorithms that minimize the shininess of the surface and differences in image colours due to exposure settings, white balance or lighting conditions. These factors may cause problems for photogrammetry techniques. 
Another aspect of the Close to Range technique is the importance to repeat the series of photos with an overlap of no more than $25-30^{\circ}$ of angular difference between images, as presented by Ducke et al. (2011). The authors also emphasize the necessity of using varied angles, view points and zooms to improve the reconstruction density. These improvements will bring better results to the Close to Range technique.

As mobile devices, such as smartphones and tablets, have been becoming more powerful, they represent an ideal platform for bringing 3D reconstruction to the masses (SCHÖPS et al., 2017). Nowadays, thanks to freely available software and sophisticated professional tools, even non-expert users are able to generate accurate 3D modelings from arbitrary scenes within hours (HOFER et al., 2017). These technologies will bring many possibilities of application to forestry, specially in forest inventory activities.

Schöps et al. (2017) presented an approach for reconstructing large-scale outdoor scenes through monocular motion stereo at interactive frame rates on a modern mobile device (Google Project Tango Development Kit Tablet). The fisheye camera of the device enables the user to reconstruct large scenes in only a few minutes by simply walking through the scene. Perhaps, in a few years, we will be able to easily reconstruct not just individual trees, but multiple trees in plots by just walking with mobile device through the environment.

\section{CONCLUSIONS}

The results obtained in present study allowed us to conclude that:

- It was possible to model 3D parts of Tectona grandis L.f trunks and logs using the Close to Range methodology and digital photogrammetry software;

- It was possible to model lower $\operatorname{logs}(0.10 \mathrm{~m}$ to $2.45 \mathrm{~m})$ more accurately by using the $3 \mathrm{D}$ scanning than by using the traditional Smalian method, considering one meter sections;

- By the methodology used for 3D scanning, logs above 2.45 meters in height tend to underestimate the trunk volume;

- For logs above $2.45 \mathrm{~m}$, the Smalian method had higher volume accuracy than the 3D modeling.

- The Smalian method with intervals of one meter between sections did not result in volume accuracy for the first commercial $\log (0.10 \mathrm{~m}$ to $2.45 \mathrm{~m})$.

\section{REFERENCES}

BUCK, A. L. B.; SILVA, M. N.; LINGNAU, C.; MACHADO, A. M. L.; MARTINS NETO, R. P.; PESCK, V. A. Avaliação da modelagem tridimensional do tronco de Pinus elliottii a partir de dados laser terrestre. Ambiência, Irati, v. 8, n. 4, p. 549-557, 2012.

BUCK, A. L. B.; SILVA, M. N.; LINGNAU, C.; MACHADO, A. M. L.; MARTINS NETO, R. P. Um algoritmo para filtragem do tronco em nuvem de pontos laser terrestre de árvores de pinus spp. Bol. Ciênc. Geod., sec. Artigos, Curitiba, v. 20, no 4, p.806-829, 2014.

CARVAlHO, S. P. C.; RODRIGUEZ, L. C. E.; SILVA, L. D.; CARVALHO, L. M.; CALEGARIO, N.; LIMA, M. P.; SILVA, C. A.; MENDONÇA, A. R.; NICOLETTI, M. F. Predict volume of trees integrating Lidar and Geostatistics. Sci. For., Piracicaba, v. 43, n. 107, p. 627-637, September 2015.

DEAN, C. Calculation of wood volume and stem taper using terrestrial single-image close-range photogrammetry and contemporary software tools. Silva Fennica, Finland, v. 37, n. 3, p. 359-380, 2003.

DUCKE, B.; SCORE, D.; REEVES, J. Multiview 3D reconstruction of the archaeological site at Weymouth from image series. Computers \& Graphics, v. 35, n. 2, p. 375-382, 2011.

FIGUEIREDO, E. O.; OLIVEIRA, M. V. N.; LOCKS, C. J.; PAPA, D. A. Estimativa do volume de madeira em pátios de estocagem de toras por meio de câmeras rgb instaladas em aeronaves remotamente pilotadas (ARP). Boletim de Pesquisa e Desenvolvimento. Rio Branco, AC: Embrapa Acre, 2016.

GUO, M.; SHI, H.; ZHAO, J.; LIUA, P.; WELBOURNE, D.; LINC, Q. Digital close range photogrammetry for the study of rill development at flume scale. Catena, v. 143, p. 265-274, August 2016.

HOFER, M., MAURER, M., BISCHOF, H. Efficient 3D scene abstraction using line segments. Computer Vision and Image Understanding, v. 157, 167-178, 2017. https://doi.org/10.1016/j.cviu.2016.03.017

JIANDONGA, Z; LIYANA, Z; DU XIAOYUA. Accurate 3D target positioning in close range photogrammetry

FLORESTA, Curitiba, PR, v. 48, n. 2, p. 225-234, abr/jun. 2018.

Chaves. A. G. S. et.al.

ISSN eletrônico 1982-4688

DOI: $10.5380 /$ rf.v48 i 2.55224 
with implicit image correction. Chinese Journal of Aeronautics, v. 22, p.649-657, 2009.

LUHMANN, T.; FRASER, C.; MAAS, H. Sensor modeling and camera calibration for close-range photogrammetry. ISPRS Journal of Photogrammetry and Remote Sensing, v. 115, p. 37-46, May 2016.

LUHMANN, T. Close range photogrammetry for industrial applications. ISPRS Journal of Photogrammetry and Remote Sensing, v. 65, p. 558-569, 2010.

MAAS, H. -G., BIENERT, A., SCHELLER, S., KEANE, E. Automatic forest inventory parameter determination from terrestrial laser scanner data. International Journal of Remote Sensing, v. 29, p. 1579-1593, 2008. <https://doi.org/10.1080/01431160701736406>

MARTINS NETO, R. P.; BUCK, A. L. B.; SILVA, M. N.; LINGNAU, C.; MACHADO, A. M.; PESCK, V. A. Avaliação da varredura laser terrestre em diferentes distâncias da árvore para mensurar variáveis dendrométricas. Boletim de Ciências Geodésicas, v. 19, n. 3, p. 420-433, September 2013.

OLIVEIRA, L. T.; FERREIRA, M. Z.; CARVALHO, L. M. T.; FERRAZ FILHO, A. C.; OLIVEIRA, T. C. A.; SILVEIRA, E. M. O.; ACERBI JUNIOR, F. W. Determinação do volume de madeira em povoamento de eucalipto por escâner a laser aerotransportado. Pesquisa Agropecuária Brasileira, v. 49, n. 9, p. 692-700, set. 2014.

ROBLEDA, P. G; PÉREZ, R. A. Modeling and accuracy assessment for 3d-virtual reconstruction in cultural heritage using low-cost photogrammetry: surveying of the "santa maría azogue" church's front. ISPRS International Archives of the Photogrammetry, Remote Sensing and Spatial Information Sciences, v. XL-5/W4, p. 263-270, 18 fev. 2015.

RODRIGUEZ, L. C. E.; POLIZEL, J. L.; FERRAZ, S. L. de B.; ZONETE, M. F.; FERREIRA, M. Z. Inventário florestal com tecnologia laser aerotransportada de plantios de Eucalyptus spp no Brasil. Ambiência, Irati (PR), v.6, Special Edition, p.67-80, 2010. 